\title{
UPAYA MENINGKATKAN HASIL BELAJAR SISWA DENGAN PROJECT BASED LEARNING MELALUI PENUGASAN MEMBUAT VLOG MATERI TRIGONOMETRI
}

\author{
Ely Hendriani \\ IKIP Siliwangi, Jl. Terusan Jendral Sudirman, Cimahi Tengah, Kota Cimahi, Jawa Barat \\ elyraya08@gmail.com
}

\begin{abstract}
This study aims to analyze the efforts in improving student learning outcomes in class XI IPA of SMA Negeri 1 Cikarang Timur with a model of learning project base learning through the assignment of making vlogs (video blogging) of simple trigonometric equation material. The method used is classroom action research, in which the subject of this study consisted of 30 students with a total of 14 male students and 16 female students, where an increase in student learning outcomes was obtained by changing the value above the minimum completeness criteria (KKM) of 11 Students (36.67\%) to 24 Students (80\%).
\end{abstract}

Keywords: Project base learning, Vlog, Trigonometric.

\begin{abstract}
Abstrak
Penelitian ini bertujuan untuk menganalisa upaya dalam meningkatkan hasil belajar siswa kelas XI IPA SMA Negeri 1 Cikarang Timur dengan model pembelajaran project base learning melalui penugasan membuat vlog (video blogging) materi persamaan trigonometri sederhana. Metode yang digunakan adalah penelitian tindakan kelas, yang dimana subjek penelitian ini terdiri dari 30 siswa dengan jumlah siswa laki-laki sebanyak 14 siswa dan 16 siswa perempuan, yang dimana terjadi peningkatan hasil belajar siswa yaitu memperoleh perubahan nilai diatas kriteria ketuntasan minimal (KKM) dari 11 Siswa $(36,67 \%)$ menjadi 24 Siswa $(80 \%)$.
\end{abstract}

Kata kunci: Project base learning, Vlog, Trigonometri.

Kurikulum 2013 merupakan suatu kebijakan baru pemerintah dalam bidang pendidikan yang diharapkan mampu untuk menjawab tantangan dan persoalan yang akan dihadapi oleh bangsa Indonesia ke depan (Sinambela, 2017). Implementasi kurikulum 2013 merupakan salah satu upaya peningkatan mutu pendidikan formal di Indonesia, dalam implementasinya kurikulum 2013 merupakan proses pengembangan pembelajaran dan salah satunya adalah pola pembelajaran pasif menjadi pembelajaran aktif mencari (pembelajaran siswa aktif mencari semakin diperkuat dengan model pembelajaran pendekatan saintifik) serta pola belajar individu menjadi belajar kelompok (berbasis tim) (Siswanto, 2018; Maharani, 2018).

Dalam pemilihan metode pembelajaran sebaiknya guru selalu memperhatikan faktor siswa yang menjadi subjek belajar, karena setiap siswa pada dasarnya memiliki kemampuan serta cara belajar yang berbeda-beda dengan siswa yang lainnya. Perbedaan tersebutlah yang dapat menyebabkan adanya kebutuhan yang berbeda dari setiap individu siswa. Namun bukan berarti bahwa pembelajaran harus diubah menjadi pembelajaran yang individual, melainkan dibutuhkan sebuah alternatif pembelajaran yang memungkinkan terpenuhinya kebutuhan seluruh individu siswa. Pendekatan yang diterapkan pada kurikulum 2013 adalah pendekatan scientific yaitu pendekatan yang lebih menekankan pada pembelajaran yang mengaktifkan siswa dan salah satu model dalam pendekatan scientific adalah model pembelajaran berbasis proyek (project based learning). Menurut Rhem, 1998 (Suparno, 2011) Problems Based Learning (PBL) adalah stategi pembelajaran dimana siswa ditatapkan pada persoalan yang real, 
kontekstual, yang tidak terstruktur ketat dan mereka berusaha untuk menemukan pemecahannya yang berarti sehingga siswa dapat menemukan jawabannya (Al Ayubi, 2019; Timutius, 2019; Akbar, 2018; Insani, 2019). Banyak faktor yang menjadi penyebab rendahnya hasil belajar matematika siswa, salah satunya adalah ketidaktepatan penggunaan pendekatan pembelajaran yang digunakan guru di kelas. Kenyataan di lapangan menunjukkan bahwa selama ini guru masih mengajar menggunakan cara yang biasa (ceramah) dan banyak didominasi serta masih berfokus pada guru (Kamal, 2015).

Trigonometri adalah salah-satu cabang matematika yang membahas tentang sudut segitiga serta fungsinya, yaitu sinus, cosinus, dan tangen. Trigonometri dapat diaplikasikan dalam berbagai bidang, seperti science, ekonomi, teknik dan lainnya untuk memecahkan berbagai permasalahan. Dengan begitu banyak manfaat yang diperoleh dari mempelajari materi trigonometri, pada kenyataannya, masih banyak siswa yang tidak dapat mengerti tentang materi yang berkaitan dengan trigonometri. Dari hasil penelitian menurut (Bernard, 2019), “... Of the 150 students who were given the questionnaire, 87\% said trigonometry was one of the material that was felt to be heavy and frightening" yang artinya dari 150 siswa yang diberikan kuesioner, $87 \%$ mengatakan trigonometri adalah salah satunya bahan yang terasa berat dan menakutkan.

Perkembangan teknologi informasi dan komunikasi yang semakin pesat menuntut semua pihak ikut serta mengembangkan diri dan beradaptasi serta mengikuti arus dengan memanfaatkan hasil tekhnologi dalam segala aktifitas (Bungsu, 2019; Haerini, 2019). Dampak perkembangan teknologi ini berimbas pula pada proses pembelajaran dimana para pendidik harus mampu melakukan berbagai inovasi dan kreatifitas agar proses pembelajaran selalu relevan dengan perkembangan yang ada. Inovasi dan kreatifitas yang dapat dilakukan pendidik salah satunya dengan penggunaan teknologi informasi sebagai media pembelajaran (Bernard \& Senjayawati, 2019).

Media pembelajaran yang terintegrasi dalam tekhnologi informasi dapat menjadi daya tarik dan memberikan gairah belajar pada peserta didik (Rohaeti, 2019). Salahsatu hasil perkembangan tekhnologi informasi yang dapat dijadikan sebagai media pembelajaran yang menyenangkan adalah Video Blog atau Vlog. Vlog merupakan salah satu solusi untuk generasi pro gadget. Pengertian dari Vlog (video blog) ialah blog yang berwujud video. Vlog ialah satu video yang dapat berisi opini, ceritera atau aktivitas sehari-hari yang umunya ditulis pada blog (Susanti,2019). Vlog merupakan media komunikasi dan informasi berbasis video dan web yang mengkolabirasikan kreatifitas, informasi dan hiburan dalam satu hasil karya. Tulisan ini mencoba untuk mengungkapkan bagaimana Vlog dapat dijadikan media pembelajaran yang efektif dan menyenangkan untuk meningkatkan minat belajar siswa sehingga dapat mengkatkan hasil belajar siswa. Dengan penguasaan teknologi informasi dan diimplementasikan melalui media pembelajaran yang menyenangkan maka diharapkan terdapat peningkatan kualitas pembelajaran. Pada Penelitian ini guru memberikan tugas kepada siswa kelas XI IPA untuk membuat Video Blogging tentang materi persamaan trigonometri sederhana. 


\section{METODE}

Metode yang digunakan pada penelitian ini adalah penelitian tindakan kelas (PTK). Subjek dari penelitian ini adalah siswa kelas XI IPA SMA Negeri 1 Cikarang Timur dengan jumlah 30 siswa yang terdiri dari 14 siswa laki-laki dan 16 siswa perempuan. Pelaksanaan penelitian ini dimulai dari 14 Oktober 2019 sampai dengan 31 Oktober 2019 yang terbagi menjadi siklus I dan siklus II (Bernard, Afrilianto \& Carilah, 2019).

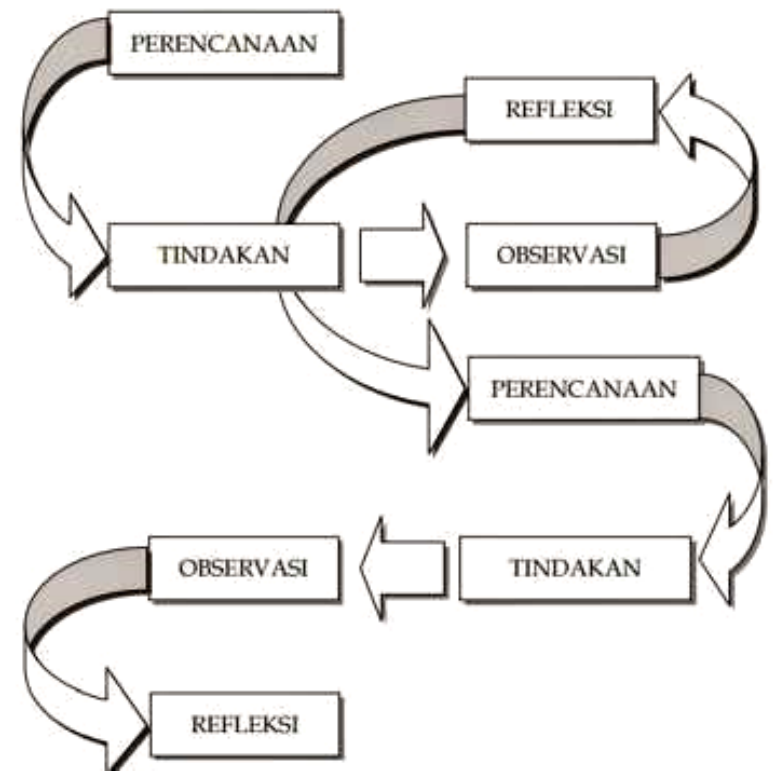

Gambar 1. Penelitian Tindakan dari Kemmis dan McTaggart

\section{HASIL DAN PEMBAHASAN}

Setelah melakukan kegiatan belajar mengajar yang dimulai dari tahap siklus I dan diakhiri di tahap siklus II pada siswa kelas XI IPA SMA Negeri 1 Cikarang Timur dengan menggunakan model pembelajaran project based learning melalui penugasan membuat vlog (video blogging) materi persamaan trigonometri sederhana, maka diperoleh peningkatan hasil belajar siswa. Salah satu faktor penyebabnya adalah perasaan senang yang dialami siswa dalam mempelajari matematika mengenai materi trigonometri sederhana sekaligus berkreasi dalam bentuk video vlog. Akibatnya, siswa kelas XI IPA SMA Negeri 1 Cikarang Timur mendapatkan peningkatan nilai, yang bisa dilihat dari tabel berikut :

Tabel 1.

Hasil Belajar Siswa

\begin{tabular}{|c|c|c|}
\hline Hasil Belajar Siswa & Siklus I & Siklus II \\
\hline Nilai di atas (KKM) & 11 Siswa (36,67\%) & 24 Siswa (80\%) \\
\hline
\end{tabular}

Dari tabel 1, dapat dilihat bahwa peningkatan hasil belajar siswa dengan menggunakan model pembelajaran project based learning berdasarkan nilai di atas Kriteria Ketuntasan Minimal (KKM) mengalami perubahan yang signifikan yaitu pada siklus I dari 11 siswa (36,67\%) menjadi 24 siswa (80\%) pada siklus II. 
Bentuk grafik peningkatan hasil belajar siswa kelas XI IPA SMA Negeri 1 Cikarang Timur dengan menggunakan model pembelajaran project based learning melalui penugasan membuat vlog (video blogging) materi persamaan trigonometri sederhana, sebagai berikut :

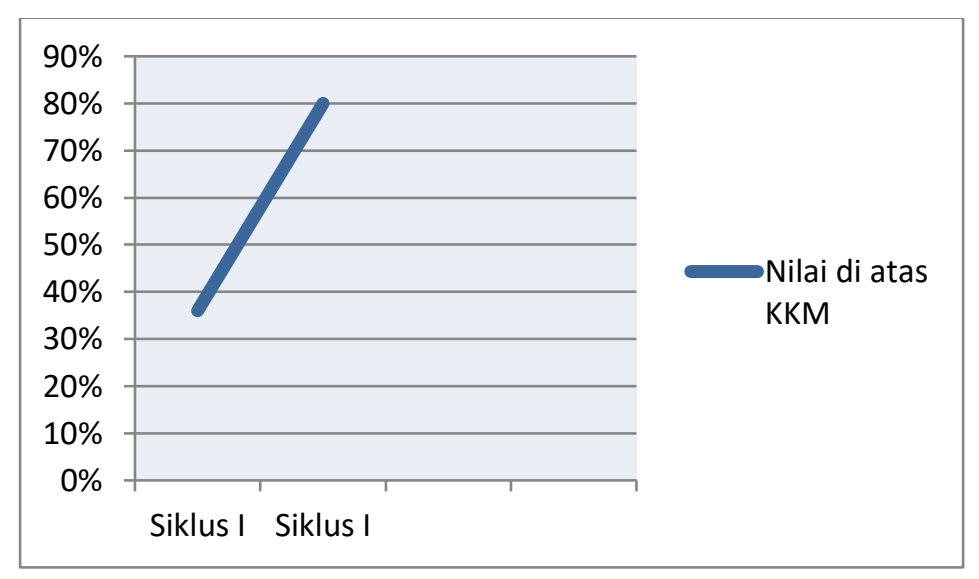

Gambar 2. Grafik Peningkatan Hasil Belajar Siswa

\section{KESIMPULAN}

Hasil penelitian tindakan kelas (PTK) yang dilaksanakan di kelas kelas XI IPA SMA Negeri 1 Cikarang Timur dengan menggunakan model pembelajaran project based learning melalui penugasan membuat vlog (video blogging) materi persamaan trigonometri sederhana mengalami peningkatan hasil belajar siswa, yaitu siswa berhasil memperoleh perubahan nilai diatas Kriteria Ketuntasan Minimal (KKM) dari 11 Siswa $(36,67 \%)$ menjadi 24 Siswa $(80 \%)$.

\section{DAFTAR PUSTAKA}

Akbar, P., Hamid, A., Bernard, M., \& Sugandi, A. I. (2018). Analisis kemampuan pemecahan masalah dan disposisi matematik siswa kelas xi sma putra juang dalam materi peluang. Jurnal Cendekia: Jurnal Pendidikan Matematika, 2(1), 144-153.

Al Ayyubi, I. I., Nudin, E., \& Bernard, M. (2018). Pengaruh Pembelajaran Berbasis Masalah terhadap Kemampuan Pemecahan Masalah Matematis Siswa SMA.JPMI (Jurnal Pembelajaran Matematika Inovatif), 1(3), 355-360.

Bernard, M., Akbar, P., Ansori, A., \& Filiestianto, G. (2019, October). Improve the ability of understanding mathematics and confidence of elementary school students with a contextual approach using VBA learning media for Microsoft Excel. In Journal of Physics: Conference Series (Vol. 1318, No. 1, p. 012035). IOP Publishing.

Bernard, M., Sumarna, A., Rolina, R., \& Akbar, P. (2019, October). Development of high school student work sheets using VBA for microsoft word trigonometry materials. In Journal of Physics: Conference Series (Vol. 1315, No. 1, p. 012031). IOP Publishing. 
Bernard, M., \& Senjayawati, E. (2019). Developing the Students' Ability in Understanding Mathematics and Self-confidence with VBA for Excel. JRAMathEdu (Journal of Research and Advances in Mathematics Education), 1(1), 45-56.

Bernard, M., \& Senjayawati, E. (2019). Meningkatkan Kemampuan Koneksi Matematik Siswa SMP dengan Menggunakan Pendekatan Metaphorical Thinking Berbantuan Software Geogebra. Jurnal Mercumatika: Jurnal Penelitian Matematika dan Pendidikan Matematika, 3(2), 79-87.

Bernard, M., Afrilianto, M., \& Carilah, C. (2018). Development of High School Students' Understanding and Confidence skills with VBA for Excel Shapes Games. In Proceedings of the 1st International Conference on Science and Technology for an Internet of Things. European Alliance for Innovation (EAI).

Bungsu, T. K., Vilardi, M., Akbar, P., \& Bernard, M. (2019). Pengaruh Kemandirian Belajar Terhadap Hasil Belajar Matematika Di Smkn 1 Cihampelas. Journal on Education, 1(2), 382-389.

Haerini, R., Fauzan, G. A., \& Bernard, M. (2019). Penerapan Model Pembelajaran Reciprocal Teaching Untuk Meningkatkan Minat Belajar Siswa Smp Di Era Teknologi. JPMI (Jurnal Pembelajaran Matematika Inovatif), 2(5), 229-236.

Insani, S. U., \& Akbar, P. (2019, October). Development of Open-Ended Based Mathematics Problem to Measure High-Level Thinking Ability. In Journal of Physics: Conference Series (Vol. 1315, No. 1, p. 012047). IOP Publishing

Kamal, S. (2015). Implementasi pendekatan scientific untuk meningkatkan kemandirian belajar matematika. Math Didactic: Jurnal Pendidikan Matematika, 1(1), 56-64.

Maharani, S., \& Bernard, M. (2018). Analisis Hubungan Resiliensi Matematik Terhadap Kemampuan Pemecahan Masalah Siswa Pada Materi Lingkaran. JPMI (Jurnal Pembelajaran Matematika Inovatif), 1(5), 819-826.

Rohaeti, E. E. (2019). Pengembangan Media Visual Basic Application untuk Meningkatkan Kemampuan Penalaran Siswa SMP dengan Pendekatan Open-Ended. SJME (Supremum Journal of Mathematics Education), 3(2), 95-107.

Sinambela, P. N. (2017). Kurikulum 2013 dan Implementasinya dalam Pembelajaran. Generasi Kampus, 6(2).

Siswanto, R. D., Dadan, D., Akbar, P., \& Bernard, M. (2018). Penerapan Model Pembelajaran Kooperatif Tipe Auditorial, Intelectually, Repetition (Air) Untuk Meningkatkan Pemecahan Masalah Siswa Smk Kelas XI. Journal on Education, 1(1), 66-74.

Sugandi, A. I., \& Akbar, P. (2019). Efektivitas Penerapan Strategi React Terhadap Kemampuan Koneksi Matematis dan Self-Efficacy Siswa SMP. Jurnal Cendekia: Jurnal Pendidikan Matematika, 3(2), 431-436. 
Suparno, P., \& Pendidikan Fisika, F. K. I. P. (2011). Penggunaan Problem Based Learning (PBL) untuk meningkatkan pengertian, kerjasama, dan minat mahasiswa dalam mempelajari termofisika. Jurnal Kependidikan, 22, 72-87.

Susanti, E. D. (2019). PROJECT BASED LEARNING: PEMANFAATAN VLOG DALAM PEMBELAJARAN SEJARAH UNTUK GENERASI PRO GADGET. Sejarah dan Budaya: Jurnal Sejarah, Budaya, dan Pengajarannya, 13(1), 84-96.

Timutius, F., Apriliani, N. R., \& Bernard, M. (2018). Analisis Kesalahan Siswa Kelas IX-G di SMP Negeri 3 Cimahi dalam Menyelesaikan Soal Pemecahan Masalah Matematik pada Materi Lingkaran. JPMI (Jurnal Pembelajaran Matematika Inovatif), 1(3), 305-312. 